\title{
EL DOLO Y LA CULPA GRAVE EN EL CONTRATO DE SEGURO
}

\author{
José A. Badillo Arias* \\ Sumario: I. Consideraciones generales. II. Inasegurabilidad de los daños causado por \\ malafe delasegurado. 1.Alcance delaexpresión "malafe del asegurado".2.Fundamento \\ de la inasegurabilidad del dolo. 3. Requisitos para que el asegurador se libere de los \\ daños dolosos. A)Lamala fe del asegurado odelas personas por las que debaresponder \\ B)Larelación de causalidadentrelaactuación dolosayel siniestro. C)Laprueba del dolo \\ delasegurado.
}

- Resumo: Não parece razoável que tenha cabimento no seguro a cobertura de atos dolosos que os segurados pratiquem, nem das pessoas que por eles devam responder. Proteger atos deliberados do segurado vai contra a legalidade dos contratos, os princípios do seguro - não é inerente a substância do contrato de seguro - e, também, estão excluídos expressamente das políticas. Esta questão, que é pacífica em seguros de danos e de pessoas em que a relação se estabelece entre o segurador e o segurado, não o é um seguro de responsabilidade civil, nos quais aparece um terceiro, alheio à relação jurídica segurador/segurado, qual a lei outorga uma proteção especial, em virtude, sobretudo, da possibilidade do exercício da ação direta do artigo 76 LCS. Este artigo analisa a polêmica que se dá entre os artigos 19 e 76 LCS. Enquanto a primeira regra é aplicável a todos os tipos de seguros, não é cabível aos atos causados por má-fé dos segurados; o segundo, no entanto, permite exigir da seguradora, inclusive nos casos de conduta dolosa do segurado.

- Palavras-chave: contrato de seguro; legalidade; dolo e culpa grave, princípios.

- $\quad$ Resumen: No parece razonable que tenga cabida en el seguro la cobertura de los actos dolosos de los asegurados ni de las que deban responder. Amparar hechos intencionados de los asegurados va en contra de la licitud de los contratos, de los principios del seguro - no existe el alea que es consustancial al contrato de seguro y, además, se excluyen expresamente en las pólizas. Esta cuestión, que es pacífica en los seguros de daños y de personas en los que la relación se establece entre el asegurador y el asegurado, no lo es en los seguros de responsabilidad civil, en los que aparece un tercero, ajeno a la relación jurídica asegurador/asegurado, al que la Ley le ortoga una protección especial, en virtud, sobre todo, de la posibilidad del ejercicio de la acción directa del artículo 76 LCS. En este trabajo analizamos la polémica que se da entre los artículos 19 y 76 LCS. Mientras el primero, norma aplicable a todas las modalidades de seguro, no da cabida a los actos causados por mala fe de los asegurados; el segundo, en cambio, permite reclamar a la aseguradora, incluso en los supuestos de hechos dolosos de los asegurados.

- Palabras-clave: contrato de seguro; licitud; dolo y culpa grave; princípios.

- Abstract: It seems unreasonable that has place in insurance the coverage for intentional acts that the insured perform or people that they should respond. Protect the deliberate acts of insured will against the legality of contracts, principles of insurance - is not inherent in the substance of the insurance contract - and, also, are expressly excluded from policies. This question, which is peaceful and safe from harm in people where the relationship is established between the insurer and the insured, is not a civil liability insurance, in which appears a third person, unrelated to the legal relationship insurer / insured, which law gives special protection, due mainly to the possibility of exercising direct action of article 76 LCS. This article examines the controversy between Articles 19 and 76 LCS. While the first rule is applicable to all types of insurance, is not

* Profesor Asociado de Derecho Mercantil Universidad Carlos III Madrid 
applicable to acts caused by bad faith of the insured; the second rule, however, require permits from the insurer, including in cases of willful misconduct of the insured.

- Keywords: insurance contract; legality; fraud and negligence; principles.

III. El dolo y los seguros de responsabilidad civil. 1. La acción directa y la "exceptio doli". 2. Aplicación del precepto a los seguros de responsabilidad civil. Especial referencia a la responsabilidad civil circulatoria. IV. Asegurabilidad de la culpa grave. V. A modo de corolario.

\section{CONSIDERACIONES GENERALES}

El art. 19 de la Ley de Contrato de Seguro alude, al igual que el anterior, a la obligación principal que tiene el asegurador de pagar la prestación. Pero a continuación establece una sola excepción al cumplimiento de tal obligación, y es el supuesto de que el siniestro haya sido causado por mala fe del asegurado.

Se ha criticado por la doctrina, no sin razón, que el precepto haga referencia a una sola excepción al cumplimiento de la obligación. La mala fe del asegurado no es el único hecho, que es lo que parece dar a entender el artículo, por el que el asegurador esté exento de llevar a cabo la prestación. La LCS -en distintos artículos como el 10, 12, 15, 17, 25, 35, 44, 47 y 52-prevé también otros casos en los que cabe que el asegurador se libere de la obligación de indemnizar, generalmente, también por una actuación intencionada del asegurado o tomador del seguro.

Por tal motivo, se ha dicho que el art. 19 LCS no pretende regular el régimen de la obligación de pago de la prestación del asegurador, sino a determinar que el asegurador no se hará cargo de la prestación en caso del que el siniestro sea causado por mala fe del asegurado. Por tanto, siempre que se alude a este precepto se hace referencia a la inasegurabilidad del dolo, por lo que la excepción, en realidad, es el contenido y alcance de este artículo.

Estamos ante uno de los preceptos de la LCS más breves y, sin embargo, uno de los más polémicos y controvertidos de la LCS, fundamentalmente, por su aparente contradicción con el art. 76 LCS, que parece indicar lo contrario. En realidad, lo que se plantea es si el asegurador debe hacerse cargo de los siniestros causados intencionadamente por su asegurado o por las personas por las que éste deba responder.

Pese a la loable postura de los tribunales de tutelar los intereses de perjudicados, víctimas de delitos dolosos, cuesta pensar, sobretodo a la industria aseguradora, que tengan que abonar siniestros causado por mala fe o dolo por parte de sus asegurados ${ }^{12}$. En este sentido, dice Soto Nieto $^{3}$, autor estudioso sobre la

${ }^{1}$ AROUILLO COLET, B. "Acción directa en el seguro de responsabilidad civil y daños dolosos de vigilantes de seguridad", InDret 2/2006, pág. 8, entiende que el hecho de que el asegurador tenga primero el deber de indemnizar no encaja bien ni con la inasegurabilidad del dolo reconocida con carácter general en el artículo 19 de la Ley de contrato de Seguro, ni con la previsión de exclusión del dolo que contienen la mayor parte de las pólizas.

${ }^{2}$ Sostiene REGLERO CAMPOS, F., Tratado de Responsabilidad Civil, Cuarta edición, vol. I, Cizur Menor 
materia y que ha mantenido una postura contraria a la jurisprudencia mayoritaria, que "la aleatoriedad que es consustancial a la institución del seguro excluye de antemano la posibilidad de dar cabida en su seno a actuaciones intencionales del asegurado, como reconoce unánimemente la doctrina". Sin embargo, como veremos, la jurisprudencia del TS, en el seguro de responsabilidad civil, desde hace algunos años, concretamente desde el acuerdo de la Sala $2^{\mathrm{a}}$ en Junta General de 14 de diciembre de 1994, que se materializó en la conocida STS (Sala 2a ) de 29 de mayo de 1997 (RJ 1997/3637), está pensando más en tutelar los intereses del perjudicado que en los principios rectores de la institución aseguradora: " $\mathrm{El}$ seguro obligatorio de responsabilidad civil derivada de la circulación de vehículos de motor no constituye tanto un medio de protección del patrimonio del asegurado como un instrumento de tutela de los terceros perjudicados. En consecuencia se trata de amparar a las víctimas frente al riesgo generado por la circulación de vehículos de motor, dando cobertura a las indemnizaciones procedentes con independencia de que el evento generador del daño sea un ilícito civil o un ilícito penal, sea culposo o doloso, siempre que el daño se haya cometido con un vehículo de motor y con motivo de la circulación".

En base a esta interpretación, se critica que esta tutela de los derechos de los perjudicados no debe ser a costa de conculcar los principios, no sólo de la institución aseguradora, sino de nuestro derecho común. Asegurar hechos intencionados supondría un ataque a la moral y al orden público que como principios rectores deben presidir la validez de los contratos, en virtud de lo que establece el art. 1.255 CC y, además, a costa de entidades aseguradoras, cuyo objeto es bien distinto, aunque, naturalmente, en sus cálculos actuariales deberán tener presente la posición de la jurisprudencia sobre la cobertura de estos hechos.

En definitiva, se interpreta por nuestros tribunales que la no asegurabilidad del dolo, lo que excluye es que el asegurador esté obligado a indemnizar al propio asegurado por un siniestro ocasionado por la mala fe de éste. Pero no impide que el asegurador responda frente a los terceros perjudicados en el caso de que en el daño o perjuicio causado a los terceros sea debido a la conducta dolosa del asegurado o bien a un acto doloso de un tercero del que se derive responsabilidad subsidiaria para aquél. En este caso, el asegurador dispone de la facultad de repetición contra el asegurado reconocida expresamente por el art. 76 de la LCS. Así lo indica la mencionada STS (Sala 2a) de 29 de mayo de 1997 (RJ 1997/3637): El art. 19 de la Ley de Contratos de Seguro, tiene su aplicación en las relaciones entre partes pero no afecta al derecho indemnizatorio propio y autónomo de la víctima del siniestro".

(Navarra), Aranzadi, 2008, pág. 1494, que el seguro cubre hechos dañosos cuyo acaecimiento es ajeno a la voluntad el asegurado (aunque tenga la causa en la conducta dolosa de un tercero). La razón es bien sencilla. El fundamento de la cobertura del seguro lo constituye la existencia del interés asegurado (arts. 25 y 26 LCS). Si éste no existe al tiempo de celebrarse el contrato o desaparece de forma sobrevenida, el seguro devienen en ineficaz por falta de ese interés. Además, la conducta dolosa supone la desaparición de la aleatoriedad propia de todo contrato de seguro. ${ }^{3}$ SOTO NIETO, F., "El seguro de responsabilidad civil general y el dolo. Solución a un tema conflictivo", Revista Española de Seguros, núm. 92, octubre-diciembre 1997, pág. 19 y ss. 


\section{INASEGURABILIDAD DE LOS DAÑOS CAUSADOS POR MALA FE DEL ASEGURADO}

\section{Alcance de la expresión "mala fe del asegurado"}

La LCS, para calificar la conducta del asegurado utiliza, en su art. 19, la expresión "mala fe", apartándose así de la terminología empleada en otros artículos en los que habla de "dolo" o "culpa grave". Así lo hacía también el Proyecto de la LCS, en el que el art. 19 disponía "el asegurador no estará obligado al pago de la prestación si el siniestro ha sido causado por dolo o culpa grave del asegurado, salvo pacto en contrario en este último supuesto. Sin embargo, subsistirá la obligación del asegurador si el siniestro es ocasionado por culpa leve del asegurado o por dolo o culpa de las personas de las que es civilmente responsable", pretendiéndose declarar la inasegurabilidad del dolo.

Ante las correspondientes enmiendas, la Ponencia del Congreso optó por sustituir la palabra "dolo" por "mala fe", principalmente, por el temor que había, entiendo 4 que por el sector asegurador, de que el dolo se identificase sólo con el dolo penal y, por tanto, sólo se exonerarían en esos casos y no en otros supuestos no delictivos, aunque sí intencionados.

En cualquier caso, la expresión "mala fe" es equiparable al dolo, en su acepción más amplia en la que se incluye también el dolo civil, expresado como la intención maliciosa de causar un daño contrario a derecho, un daño antijurídico ${ }^{5}$. La STS (Sala 1 ${ }^{\mathrm{a}}$ ) de 20 de julio de 2005 (RJ 2005/5099), equipara la mala fe con el dolo, que a su vez pude provenir de un delito o de un acto ilícito o mala fe ${ }^{6}$.

La STS (Sala 1 ${ }^{\text {a) }}$ ) de 1 de octubre de 1994 (RJ 1994/7440), establece la inasegurabilidad de la mala fe, entendida en un doble aspecto: "Consecuencia de

\footnotetext{
${ }^{4}$ Asílo indica SÁNCHEZ CALERO, F., Comentarios a la Ley 50/1980, de 8 de octubre y a sus modificaciones, $3^{a}$ edición, Cizur Menor (Navarra), Aranzadi, junio 2005, pág. 352.

${ }^{5}$ Lo relevante, dice SÁNCHEZ CALERO, F., Comentarios..., op. cit., pág. 352, es que ha de tratarse de un acto consciente y voluntario del asegurado, que quiere que se produzca el siniestro. Ha de ser un acto intencional y malicioso del asegurado.

${ }^{6}$ Dice esta sentencia que "No cabe duda alguna de que el art. $1^{\circ}$ LCS obliga al asegurador a indemnizar a los perjudicados por el daño sufrido cuando se produzca el evento cuyo riesgo es objeto de cobertura, "dentro de los límites pactados" (lo que obliga, en todo caso, a dar cumplimiento a las condiciones de la póliza, en cuanto deban aplicarse), y que el 19 exime al asegurador de dicho pago, "en el supuesto de que el siniestro haya sido causado por mala fe del asegurado" (mala fe, en la que, indudablemente, hay que incluir el acto realizado con dolo por el asegurado, con lo que se excluirían, en principio, las consecuencias civiles, no asegurables, de los actos delictivos cometidos por dicho asegurado), pero hay que tener muy en cuenta que dichos preceptos son generales (incluidos en el Título I de la Ley reguladora), aplicables, inicialmente, a todas las clases de seguros, y por lo tanto, con la salvedad de lo que al respecto se diga para algún tipo o clase específico de seguro, de los que la Ley citada regula en sus apartados propios de ellos. Indudablemente (y los seguros de robo y especialmente el de incendio, serían un exponente claro de la aplicación de esa regla), no se pueden asegurar los propios delitos cometidos por el tomador del seguro, como propio asegurado, en cuanto el dolo va unido a, o está formado por, la intención de obtener una ganancia o beneficio a través del delito o acto ilícito o de mala fe, producido, y ello con evidente perjuicio, a través del engaño o la superchería, para el asegurador".
} 
ello es que en su interpretación la más generalizada doctrina limite la inasegurabilidad de esa «mala fe» no ya sólo en su aspecto subjetivo (la conducta del asegurado omitiendo toda referencia al tomador del seguro), sino también en el objetivo, al proyectar dicha conducta sobre la causa originadora del siniestro en lugar de sobre el resultado (artículo 17.4)".

En el mismo sentido, citando la sentencia anterior, se pronuncia la STS $\mathbf{n}^{\circ}$ 639/2006 (Sala 1a) de 9 de junio de 2006, en que el asegurado de dos seguros de accidentes fallece como consecuencia de que al huir de la Guardia Civil gira en dirección contraria y colisiona con un vehículo que circulaba correctamente. El TS, al igual que lo hicieron las sentencias de instancia, desestima las pretensiones de su esposa, beneficiaria de ambos seguros, al entender que ha existido mala fe en la conducta del asegurado. Para la sentencia "puede decirse que el término "mala fe" usado por el artículo 19 LCS, lo relevante es que ha de tratarse de un acto consciente y voluntario del asegurado. Ha de ser un acta intencional y malicioso del asegurado".

Sobre lo que debe entenderse por mala fe existe una amplia jurisprudencia en supuestos del seguro de retirada del permiso de conducir cuando se produce tras la condena al asegurado por un delito contra la seguridad en el tráfico, generalmente, por la conducción bajo la influencia de bebidas alcohólicas. En estos casos, las aseguradoras rechazan las pretensiones de cobro del correspondiente subsidio por parte de los asegurados, alegando la mala fe de los mismos en la producción de los siniestros. Aunque algunas sentencias entienden que estamos en presencia, en casos de exclusión por alcoholemia, de cláusulas limitativas de los derechos de los asegurados y, por tanto, sólo las admiten si cumplen con los requisitos del art. 3 LCS; otras, en cambio, en mi opinión, más acertadamente, sobretodo cuando el asegurado ha sido condenado por un delito contra la seguridad en el tráfico, entienden que estamos ante un actuación maliciosa del mismo, siendo de aplicación el art. 19 LCS.

Este es el caso enjuiciado en la SAP de Sevilla (Sección $5^{\mathrm{a}}$ ) de $\mathbf{1 7}$ de abril de 2006 (JUR 2006/262656), en el que el actor, que reclamaba a la entidad aseguradora las cantidades correspondientes al subsidio derivado de la pérdida del permiso de conducir, tras desestimarse sus pretensiones en primera instancia, recurre la sentencia alegando en esencia que cuando un asegurado conduce un vehículo de motor bajo la influencia de bebidas alcohólicas, cuando se haya asegurado la retirada del permiso de conducir, solo incurre en mala fe con respecto al seguro concertado en el supuesto de que tal conducta sea a propósito para verse privado del carné de conducir y obtener la prestación concertada para ese caso. Sin embargo, la Audiencia, que confirma la sentencia de instancia, entiende que estamos ante un supuesto de no cobertura por mala fe del asegurado, en los siguientes términos: "Evidentemente, no puede considerarse mala fe del asegurado la mera infracción de normas administrativas en la conducción de vehículos, ni siquiera las relativas al consumo de alcohol. Tampoco 
puede presumirse la existencia de mala fe aunque la conducta sea calificada de delictiva, por cuanto que la peligrosidad de la circulación de vehículos de motor puede llevar a la comisión de errores o equivocaciones producto de la imprevisión humana que tengan graves consecuencias. Ahora bien, cuando la infracción ha merecido la calificación en la jurisdicción penal de un delito doloso contra la seguridad del tráfico, ha de considerarse acreditado que el demandado conducía un vehículo de motor a pesar de ser necesariamente consciente de que el alcohol ingerido había disminuido gravemente su capacidad para conducir, lo que sin duda alguna supone una elevación notoria del riesgo normal de incurrir en una sanción grave de privación del permiso de conducir que no estaba expresamente prevista en el contrato. Esta conducta del demandante es contraria a los más elementales imperativos éticos de la conciencia social y por ende a la buena fe contractual, que impone al asegurado no someter a riesgos desproporcionados y exorbitantes lo que es objeto del seguro, por lo que nunca puede entenderse cubierta salvo que se prevea específicamente. En definitiva, la mala fe contractual existe cuando el asegurado de forma consciente y voluntaria realiza una conducta reprochable socialmente, en este caso tan reprochable que es sancionada penalmente, no prevista expresamente en el contrato y que incrementa desproporcionadamente y fuera de los límites que han de considerarse normales el riesgo objeto de cobertura, revelando tal conducta una falta de lealtad contractual en el cumplimiento de sus obligaciones que libera a la compañía aseguradora de su deber de pagar la prestación a tenor del artículo 19 de la Ley de Contrato de Seguro".

No obstante, hay opiniones en contra de esta hipótesis que entienden que, en todo caso, se debe hacer una interpretación restrictiva del concepto de mala fe en determinados tipos de seguros. De este modo, consideran que hacer un análisis como el indicado desnaturaliza el seguro de retirada del carné de conducir, dejándolo vacío de contenido porque necesariamente el siniestro va a conllevar una actuación dolosa del asegurado, ya sea mediante una sanción administrativa o penal. Por tanto, en este caso, la exclusión, si cabe, sería una cláusula limitativa de los derechos del asegurado y, en consecuencia, debería estar sometida a los requisitos del art. 3 LCS.

Ésta es precisamente la posición que mantiene el alto tribunal en la STS (Sala 1 ${ }^{\text {a)}), ~ d e ~} 7$ julio de 2006 (RJ 2006\6523). En este caso, el asegurado de un seguro de accidentes falleció al invadir con su vehículo el carril contrario y colisionar con otro que circulaba correctamente. La autopsia reveló que la concentración de alcohol etílico en sangre del conductor asegurado, en el momento del siniestro, era de $2,7 \mathrm{gr} . / \mathrm{l}$.

La Sala indica las dos posiciones sostenidas por las AAPP sobre esta cuestión. Por una lado, la que acepta que la exclusión del accidente en tales circunstancias tiene validez cuando figura una cláusula que, como limitativa de los derechos del asegurado, aparece resaltada y específicamente aceptada por 
éste y, por otro, la que rechaza que el siniestro, aún cuando no figure válidamente en la póliza ninguna de dichas cláusulas, no se halla bajo la cobertura del contrato de seguro, por aplicación del art. 19 LCS, que excluye los siniestros causadas por mala fe del asegurado. En la argumentación tendente a sustentar esta última tesis suele aludirse al hecho de que la conducción en contra de lo prevenido en la Ley o incurriendo en conductas penalmente castigadas implica un hecho intencional que no puede ser objeto de cobertura por el contrato de seguro, pues el que actúa bajo la influencia de bebidas alcohólicas es consciente de que infringe el ordenamiento jurídico aunque el resultado dañoso no sea querido. Tampoco es infrecuente hacer referencia a la gran sensibilidad social existente en la actualidad en relación con los accidentes de circulación causados por conductores que superan la tasa de alcoholemia legalmente permitida.

El TS, que se decanta por la primera tesis, hace un análisis exhaustivo de cómo debe interpretarse el art. 19 LCS, haciendo referencia, en particular, a los siniestros en los que los asegurados superan las tasas de alcoholemia legalmente establecidas: "La intencionalidad que exige la LCS para que concurra esta exclusión no se refiere en abstracto a cualquier conducta de la que se siga el resultado del siniestro, sino a la causación o provocación de éste. Admitir que, por principio, todo resultado derivado de una conducta tipificada como delictiva, aunque se trate de figuras de riesgo, no puede ser objeto de aseguramiento (dado que la exclusión de los supuestos de mala fe del asegurado responde a razones de moralidad del contrato ligadas a la licitud de su causa) no es compatible, desde el punto de vista lógico-formal, con el principio de libre autonomía de la voluntad que rige en esta materia contractual; $\mathrm{y}$, desde una perspectiva lógico-material, no soporta una verificación del argumento cuando se contrasta con sus consecuencias desproporcionadas y contradictorias en relación con el ámbito usual del contrato de seguro y con el contenido que le asigna la Ley en diversas modalidades obligatorias relacionadas con actividades susceptibles de causar accidentes. La exclusión de la cobertura del seguro de los siniestros ocasionados o padecidos por el asegurado conduciendo un vehículo de motor en situación de exceso de alcoholemia no puede aceptarse, aun reconociendo la gran relevancia de la función social del seguro, y aunque se considere necesaria su introducción en virtud de políticas de prevención o de otra índole, si no es objeto de una previsión específica en la norma. Así ocurre actualmente, a raíz de la transposición de normas de orden comunitario, en la regulación del seguro de responsabilidad civil en la circulación de vehículos de motor, aunque únicamente respecto del asegurado y no respecto del tercero que ejercita la acción directa como víctima o perjudicado (art. 10.a de la Ley de Responsabilidad Civil y Seguro de la Ley de Vehículos de Motor [RCL 1968, 690] y 9.4 de su Reglamento [RCL 2001, 126] y sentencias del Tribunal Superior de Justicia de las Comunidades Europeas de 28 de marzo de 1996). En otro caso, sólo cabe su introducción en las cláusulas de la póliza, pues, aun cuando es indudable que la ingestión excesiva de bebidas 
alcohólicas y la consiguiente conducción aumenta el riesgo de siniestro, no toda situación que incremente el riesgo debe equipararse a la existencia de dolo, intencionalidad o mala fe y son las aseguradoras quienes, en la economía del contrato de seguro, deben ponderar, mientras lo permita la Ley, con sujeción a los requisitos en ella establecidos, la oportunidad de excluir determinados riesgos en uso de la libertad de pactos".

Por otro lado., la mala fe no se presume, sino que tiene que ser probada por la entidad aseguradora que la alega, para liberarse de cumplir su prestación. Así lo indica la STS (Sala 1ª) de 7 de noviembre de 1997 (RJ 1997/7936), en un supuesto de robo en el que la aseguradora invocaba que fue el asegurado el que provocó la sustracción: "La mala fe no se presume, sino que debe ser examinada y apreciada por el Tribunal de Apelación, y exige e impone la carga de la correspondiente prueba a cuenta de la entidad aseguradora, lo que aquí no ha sucedido, pues no se cumple tal exigencia con aportación de simples insinuaciones y sospechas, que es la actividad procesal llevada a cabo por la recurrida y menos al no quedar acreditado y consolidado como hecho firme que el asegurado fuera el que provocó o llevó a cabo la sustracción denunciada".

En supuestos similares, que se dan con relativa frecuencia, en los que las entidades aseguradoras alegan la simulación de un siniestro, ésta es también la posición que han mantenido las Audiencias Provinciales, como puede verse en la SAP de las Palmas (Sección 5a) de 7 de junio de 2005 (JUR 2005/87011), la SAP de Tarragona (Sección 1a) de 16 de marzo de 2004 (JUR 2004/155691), o la SAP de Murcia de 17 de octubre de 2003 (JUR 2003/276571).

Se dice también que no es suficiente la intencionalidad del sujeto, aspecto subjetivo, sino que debe proyectarse sobre la producción del siniestro, como lo explica la STS (Sala 1'a) de 5 de julio de 1990 (RJ 1990/5776) ${ }^{7}$.

\section{Fundamento de la inasegurabilidad del dolo}

La inasegurabilidad de los actos intencionados es consustancial al contrato de seguro, en el que "el alea", como elemento sobre el que gira la institución aseguradora, es ajeno a la voluntad e intencionalidad del asegurado. No se pueden asegurar hechos que dependan de la voluntad de la persona, pues lo que caracteriza el seguro es precisamente la incertidumbre del "evento cuyo riesgo es objeto de cobertura", tal como señala el art. 1 LCS.

\footnotetext{
${ }^{7}$ Indica esta STS, que "La buena o mala fe en el actuar del asegurado necesariamente ha de conectarse con la producción del evento o siniestro de que se trata, de modo que si éste no está probado queda en suspenso o mera hipótesis la valoración que en este otro motivo se pretende, distorsionando además el recurrente el sentido y alcance de la casación, habida cuenta que la estimación de buena o mala fe es una cuestión de hecho reservada a la apreciación potestativa de los tribunales de instancia, que ha de prevalecer siempre que no resulte ilógica o manifiestamente equivocada, todo ello en la medida en que la buena fe (o, en su caso, la mala fe) es un concepto jurídico que se apoya en la valoración de una conducta deducida de unos hechos. Procede, en consecuencia, la desestimación de los dos motivos en que ha quedado concretado el presente recurso, tras el rechazo del primero formulado al amparo del n. ${ }^{\circ} 4$ del art. 1692 de la L.E.C".
} 
Así se deduce del articulado de la LCS y, sobretodo, del art. 19 LCS que estable la exclusión de los daños intencionados, tal como establece la STS (Sala 1a) de 8 de junio de 1999 (RJ 1999/4102). Este artículo, situado en la Sección Tercera del Título Primero, es aplicable a todas las modalidades de seguro y no sólo, como estamos viendo, a los seguros de daños propios. La STS (Sala 2a) de 27 de noviembre de 1989 (RJ 1989/9326), indica que sólo es asegurable la culpa, ya sea grave o leve, pero nunca el dolo 8 .

Además, asegurar conductas intencionadas iría en contra de la moral y del orden público, como puso de manifiesto la STS (Sala 2a) de 14 de marzo de 1991 (RJ 1991/2139): "Es indudable que las excepciones establecidas en los arts. 19 y 48 de la LCS responden a una exigencia esencial del contrato de seguro. Asegurar los siniestros causados por dolo o mala fe sería contrario al orden público (vid. art. 1255 del Código Civil)".

Sin embargo, como ya hemos advertido, desde 1997, tras la STS (Sala $2^{\text {a) }}$ ) de 29 de mayo de 1997 (RJ 1997/3637), el TS mantiene que la inasegurabilidad del dolo sólo es aplicable al propio asegurado cuando el siniestro ha sido causado intencionadamente. Pero no es oponible, en cambio, al perjudicado, en virtud de lo dispuesto en el art. 76 LCS $^{9}$.

\footnotetext{
${ }^{8}$ Lo expresa de la siguiente forma: "'En relación con esta cuestión, es preciso tener en cuenta que, según establece el artículo 19 de la Ley de Contrato de Seguro, uel asegurador estará obligado al pago de la prestación salvo en el supuesto de que el siniestro haya sido causado por mala fe del aseguradon. De ello cabe concluir que es asegurable la culpa del asegurado -sea grave o leve-, y que, por ende, en estos supuestos quedará obligada la entidad aseguradora (vid. artículo 73 de la Ley de Contrato de Seguro). Es decir que únicamente quedan fuera del ámbito potencial del contrato de seguro de responsabilidad civil la responsabilidad penal propiamente dicha y la civil "derivada de hechos dolosos»".

${ }_{9}^{9}$ Así lo expone con claridad La STS (Sala 2a) de 11 de marzo de 2002 (RJ 2002/6891): "Se dice que la tesis que sostiene la negativa absoluta a que el seguro de responsabilidad civil pueda indemnizar a las víctimas de siniestros ocasionados en el ámbito de la cobertura del seguro, pero derivados de una acción dolosa del causante del daño (que puede ser, o no, el asegurado) se fundamenta en el denominado principio de no asegurabilidad del dolo, que se considera un principio inminente al derecho especial de seguros. Este principio no aparece explicitado en el Ordenamiento positivo español, pero los partidarios de su vigencia lo incardinan en el art. 19 de la Ley de Contrato de Seguro (Ley 50/1980, de 8 de octubre) que establece que «El asegurador estará obligado al pago de la prestación, salvo en el supuesto de que el siniestro haya sido causado por la mala fe del asegurado». Sin embargo, la Sala Segunda del Tribunal Supremo no interpreta dicho principio con el carácter absoluto con el que se sostiene por parte de la doctrina más favorable a las tesis de las compañías aseguradoras, sino que mantiene una interpretación alternativa, más sensible a los intereses de las víctimas o perjudicados y más adecuada a la naturaleza y función del seguro de responsabilidad civil. Así la Sala ha señalado reiteradamente (por ejemplo en sentencias de 29 de mayo y 24 de octubre de 1997 [RJ 1997, 3637], de 11 de febrero y 4 de diciembre de 1998 [RJ 1998, 1046 y 10325], y de 17 de octubre de 2000 [RJ 2000, 9152], entre otras) que el seguro de responsabilidad civil constituye tanto un medio de protección del patrimonio del asegurado como un instrumento de tutela de los terceros perjudicados. Desde esta perspectiva el principio de no asegurabilidad del dolo, acogido en el art. 19 de la Ley de Contratos de Seguro, lo que excluye es que el asegurador esté obligado a indemnizar al propio asegurado por un siniestro ocasionado por la mala fe de éste, pero no impide que el asegurador responda frente a los terceros perjudicados en
} 


\section{Requisitos para que el asegurador se libere de los daños dolosos}

\section{A) La mala fe del asegurado o de las personas por las que deba responder}

Como hemos señalado, para que el asegurador se libere de cumplir la prestación es necesario que el evento haya sido causado por mala fe del asegurado, entendida ésta como equiparable al dolo y no sólo al dolo penal, sino al dolo tal y como ha sido elaborado por la doctrina civilista. Por tanto, la conducta del asegurado requiere un acto consciente, voluntario y antijurídico ${ }^{10}$.

La cuestión que debemos plantearnos es si el art. 19 LCS se refiere sólo al asegurado y, por tanto, los hechos intencionados de otras personas, como el tomador o el beneficiario, no liberarían a las aseguradoras o, por el contrario, la referencia al asegurado hay que entenderla de una forma amplia. La doctrina se ha inclinado por una interpretación literal del precepto, pues cuando la ley ha querido referirse a otros sujetos, lo ha hecho, como por ejemplo, en el seguro de vida o de accidentes, en los que el beneficiario pierde su derecho a la prestación cuando haya causado dolosamente la muerte o el accidente del asegurado. Así lo entiende también la STS (Sala 1 ${ }^{\text {a) }}$ de 1de octubre de 1994 (RJ 1994/7440), que declara que la mala fe, en su aspecto subjetivo, se limita al asegurado porque el precepto omite toda referencia al tomador del seguro.

La STS (Sala 1a) de 31 de marzo de 2004 (RJ 2004/2071), nos proporciona un ejemplo de la postura indicada. En este caso, el tomador del seguro, que era arrendatario de una nave, provoca un incendio en el que se causan daños en su maquinaria y en la nave, que era propiedad del arrendador. El TS entiende que los daños ocasionados en su maquinaria no son indemnizables, al ser causante del incendio y asegurado. Sin embargo, los daños en la nave sí deben ser indemnizados por la aseguradora porque el titular del interés asegurado, en este caso, es el arrendador, que es el propietario de la nave y los daños fueron causados por el tomador.

Por otro lado, debemos preguntarnos si lo establecido en el art. 19 LCS, afecta también a las personas por las que el asegurado debe responder. Por tanto, en el supuesto en el que éstas causen un siniestro de forma maliciosa, la aseguradora quedaría también exonerada de cumplir con su prestación. Existe unanimidad., tanto en la doctrina como en la jurisprudencia, en que el art. 19 LCS sólo se refiere al

el caso de que el daño o perjuicio causado a los terceros sea debido a la conducta dolosa del asegurado, disponiendo en este caso el asegurador de la facultad de repetición contra el asegurado reconocida expresamente por el art. 76 de la Ley de Contrato de Seguro".

${ }^{10}$ La SAP de León (Sección 1 ${ }^{\mathrm{a}}$ ) de 11 de octubre de 2002 (JUR 2002/6214), nos define el dolo civil como: "(...) todo artificio, engaño o fraude que induce a error en otra persona realizando un acto que de otro modo no habría consentido. Se distingue por la doctrina entre dolo causante y dolo incidental, siendo el primero realmente transcendente a la hora de valorar la eficacia o no de los negocios jurídicos. Como requisitos del dolo se pueden clasificar los siguientes: $1^{\circ}$ ) La existencia del engaño producido por cualquier medio. $2^{\circ}$ ) La intención de producir engaño. $3^{\circ}$ ) La influencia del engaño de manera determinante sobre el negocio jurídico. Al dolo se refiere el Código Civil, en varios preceptos (art. 673, 1.265, 1.269 y 1.270), siendo un hecho pacífico que el dolo da lugar a la nulidad del acto o contrato, salvo que sea incidental". 
asegurado y no a otras personas por las que éste deba responder, por lo que los actos dolosos de éstos deben ser asumidos por las aseguradoras. Así lo establece la SAP de Barcelona (Sección 2a) de 9 de abril de 2001 (JUR 2001/209892), que fue confirmada por la STS (Sala 2a) de 28 de marzo de 2003 (RJ 2003/2692), al establecer: "Dejando al margen la alegación de que en todo caso las lesiones dolosas llevadas a cabo por el acusado no estarían cubiertas por la póliza de responsabilidad civil en base a lo dispuesto en el artículo 19 de la Ley de Contrato de Seguro por carecer de fundamento jurídico en cuanto en dicho artículo se alude a la "mala fe del asegurado" y el asegurado lo era en el supuesto de autos la Discoteca Ecologic y no Juan N. B".

Con cierta frecuencia, se producen hechos delictivos por parte de los dependientes, generalmente asalariados, que están fuera de sus funciones, bien porque no ocurren en el lugar de trabajo, bien porque se extralimitan en las mismas. En estos casos, la jurisprudencia no duda en condenar como responsables civiles directas, en virtud del art. $117 \mathrm{CP}$, a las entidades aseguradoras que cubren la responsabilidad civil del empleador que, a su vez, es condenado como responsable civil subsidiario. El argumento, normalmente, se basa en la culpa "in iligendo" o "in vigilando". Así ocurrió en el supuesto analizado en la STS (Sala $2^{\mathrm{a}}$ ) de 17 de octubre de 2000 (RJ 2000/9152), en el que un socio trabajador de una cooperativa cuyo objeto era el cuidado de niños, fue condenado por un delito de abusos deshonestos, condenando también como responsable civil subsidiaria a la cooperativa y a su compañía aseguradora como responsable civil directa: "La asegurada ha sido declarada responsable civil subsidiaria en base a unos hechos realizados por un trabajador dependiente de la misma en el ámbito de su actividad laboral propia, concurriendo por su parte acción u omisión culposa o negligente consistente en error "in vigilando" o «in eligendo», sirviendo precisamente la póliza otorgada como medio de cobertura de la responsabilidad civil declarada frente a la misma, siguiéndose por ello la adecuación del riesgo producido a las condiciones pactadas en el contrato de seguro de responsabilidad civil".

Una argumentación similar utiliza la STS (Sala 1a) de 20 de julio de 2005 (RJ 2005/5099), en un caso en el que se produce un doble asesinato por parte de un vigilante jurado en un lugar alejado en 1240 metros de la cantera en la que tenía encomendadas sus labores de vigilancia, en el que la compañía aseguradora defendía, entre otras cosas, que el suceso ocurrió fuera de su ámbito laboral.

\section{B) La relación de causalidad entre la actuación dolosa y el siniestro}

No basta con la intencionalidad del sujeto, sino que ésta debe proyectarse sobre el siniestro. Deber haber, por tanto, relación de causalidad entre la actuación dolosa del asegurado y el siniestro. Así lo indica la STS (Sala $1^{\mathrm{a}}$ ) de 1 de octubre de 1994 (RJ 1994/7440), cuando dice que la conducta del asegurado debe proyectarse "sobre la causa originadora del siniestro en lugar de sobre el resultado" o la STS (Sala $1^{\text {a) }}$ de 5 de julio de 1990 (RJ 1990/5776), que establece que "la buena o mala fe en el actuar del asegurado necesariamente ha de conectarse con la producción del evento 
o siniestro de que se trata, de modo que si éste no está probado queda en suspenso o mera hipótesis la valoración que en este otro motivo se pretende"

\section{C) La prueba del dolo del asegurado}

Corresponde a la entidad aseguradora la carga de la prueba de que el siniestro ha sido causado por mal fe del asegurado, rechazándose, en general, la prueba de presunciones. Así lo establece la STS (Sala 1ª) de 7 de noviembre de 1997 (RJ 1997/ 7936), al decir que "la mala fe no se presume, sino que debe ser examinada y apreciada por el Tribunal, y exige e impone la carga de la correspondiente prueba a cuenta de la entidad aseguradora".

Por tanto, sólo cuando el asegurador acredite la mala fe del asegurado y que tal actuación del asegurado ha provocado intencionada y maliciosamente el siniestro, el asegurador no estará obligado al pago de la prestación. Esto, en sentido estricto es así, no porque se libere de su obligación, sino porque el derecho de crédito del asegurado, en tales supuestos, no ha surgido, hecho que al ser impeditivo ha de ser probado por el asegurador, tal como ya hemos señalado.

\section{EL DOLO Y LOS SEGUROS DE RESPONSABIIDAD CIVIL 1. La acción directa y la "exceptio doli"}

Ya nos hemos referido a la aparente contradicción que existe entre los artículos 19 LCS y 76 LCS, pues, mientras que por el primero, no tienen cabida dentro del seguro los hechos maliciosos del asegurado; el segundo, en cambio, permite al perjudicado el ejercicio de la acción directa contra el asegurador para exigirle el cumplimiento de la prestación, "sin perjuicio del derecho del asegurador a repetir contra el asegurado, en el caso de que sea debido a conducta dolosa de éste, el daño o perjuicio causado a tercero".

La polémica se ha decantado por entender que, al menos, en el seguro de responsabilidad civil ${ }^{11}$, las aseguradoras deben hacerse cargo de las consecuencias derivadas de los hechos dolosos de los asegurados o de las personas por las que respondan, no pudiendo oponer al perjudicado la "exceptio doli"12 ${ }^{13}$. Se trata, pues,

\footnotetext{
${ }^{11}$ Sobre esta cuestión, vid. MAZA MARTÍN, J.M., "jurisprudencia del dolo en siniestros de responsabilidad civil", X Congreso de Responsabilidad Civil y Seguro, INESE, Madrid, octubre de 2009.

${ }^{12}$ Vid. HEBRERO ALVÁREZ J.I., "Comentarios a los aspectos civiles y aseguradores de la sentencia de la Audiencia Provincial de Valencia de mayo de 2007 (caso del anestesista Maeso)", Revista de Responsabilidad Civil, Circulación y Seguro, $\mathrm{N}^{\circ} 7$, julio-agosto 2007, pág. 5 y ss. Indica que no se aceptó por el tribunal la "exceptio doli" o inasegurabilidad del dolo, que las defensas de las aseguradoras de responsabilidad civil habían planteado. Para este autor, en cualquier relación contractual se impone el principio general de la buena fe. Ésta no es más que un modelo o un arquetipo de conducta social; una norma de conducta. Y como acertadamente se apunta a menudo, esta norma que impone un comportamiento de buena fe en la vida jurídica es un principio general del derecho. La buena fe inspira el ordenamiento jurídico. Por ello, las pólizas de seguro españolas excluyen aquellos siniestros ocasionados voluntaria e intencionadamente por el propio asegurado, ya que el dolo excluido es un hecho voluntario e ilícito, que tiene como propósito provocar un evento que apareje, como necesaria consecuencia, un perjuicio propio o a terceros, pero que no requiere necesariamente la intención de
} 
de proteger a las víctimas, permitiéndoles no sólo el ejercicio de la acción directa, sino la posibilidad de ser indemnizados por las entidades aseguradoras por hechos dolosos de los asegurados, a las que sólo se les permite la acción de repetición contra los mismos. El profesor Yzquierdo Tolsada ${ }^{14}$, reconoce que la acción directa otorga a la víctima un derecho propio que no deriva del contrato. Por tanto, no se ve afectado por las exclusiones de cobertura, entendiendo que al asegurador sólo le queda ejercitar, en tales casos, la vía de regreso, y que ése es su riesgo de empresa: que en el regreso el asegurado demandado resulte insolvente.

Pese a que, como veremos, en la actualidad la cuestión es pacífica, al menos en lo que a la jurisprudencia del TS se refiere, (no sólo de la Sala $2^{\text {a }}$, que por razones obvias ha tratado con más profundidad el asunto, sino también la $1^{a}$, como muestra la reciente STS (Sala 1a) de 20 de julio de 2005 (RJ 2005/5099), que acoge como suyos los argumentos de la Sala $2^{\mathrm{a}}$ ), ha habido voces discrepantes de esta posición, entre las que destacamos la de Soto Nieto ${ }^{15}$, que ha sostenido en múltiples trabajos sobre la materia, que no pueden tener cabida dentro del seguro los hechos intencionados del asegurado. El siniestro, dice, "ha de provenir de eventos aleatorios, nunca voluntarios conforme a un obrar consciente y potestativo, (...) el azar del acaecer siniestral con que se cuenta en el seguro de responsabilidad civil cae por tierra en el hecho doloso". También ha mantenido esta posición en distintas resoluciones judiciales del TS, de las que extraemos un fragmento de su voto particular emitido en la STS (Sala 2a) de 29 de mayo de 1997 (RJ 1997/3637), que, como hemos indicado, supuso un cambio en la doctrina del alto tribunal, que perdura en la actualidad. En dicho voto particular explica el alcance que se le debe dar al art. 76 LCS: "Los preceptos citados -artículo 76 LCS y artículo 7, a) de la Ley 30/1995- han de ser entendidos en función de una reclamación normal de víctima o perjudicado frente al asegurador, inexistente pronunciamiento judicial que conceptúe la conducta del asegurado como obediente a un propósito de atentar contra la vida, la integridad o los bienes de un tercero. Aun estos hechos de dolosa gestación suelen revestirse de aparentes siniestros fortuitos o producto de un proceder descuidado o negligente. El asegurador

causar daño al asegurador, o la de obtener provecho en favor del agente doloso, pues en este caso nos hallaríamos ante una estafa, y sí, en cambio, la intención importa el conocimiento de que al provocarlo ponía en juego la garantía prometida por el asegurador. El contrato de seguro tiene sus pilares en la buena fe, como todos los contratos, sólo que el seguro es en más alto grado, uberrima fidei, lo que tiene un fundamento extensible en la intangibilidad de la mercancía que constituye su objeto y en la imprecisa consistencia de los elementos que se utilizan para regular el precio de ella" ${ }^{13}$ Señala REGLERO CAMPOS, F., Tratado de Responsabilidad Civil, Cuarta edición, vol. I, Cizur Menor (Navarra), Aranzadi, 2008, pág. 1490, que, por regla general, la jurisprudencia se ha mostrado muy reacia a admitir la "exceptio doli" en las reclamaciones contra el asegurador de RC.

${ }^{14}$ Vid. YZQUIERDO TOLSADA, M., Aspectos civiles del nuevo Código Penal, Dykinson, 1997, pág. 210.

${ }^{15}$ Seguramente sea SOTO NIETO el más firme defensor de la exclusión de este tipo de daños de la cobertura de esta modalidad asegurativa, y así lo ha manifestado en numerosas ocasiones: Responsabilidad civil (1989), pgs. 115 y ss. DJ 81 (1994), pg. 261; La Ley, núms. 4312 y 4313 (18 y 19 junio 1997); RES 92 (1997), pg. 19; La Ley 2001-2, pgs. 1714 y ss. La Ley 200-4, pgs. 1553 y ss. RES 106 (2001), pg. 309, entre otras. 
se ve obligado a atender la pretensión del tercero afectado, sin perjuicio de que, ulteriormente, desvelado el actuar doloso criminal del conductor causante, pueda repetir contra el mismo. No quiere el legislador que se dilate la protección en supuestos no definidos como resultado de una infracción delictual dolosa. Supuesto bien distinto del de la condena del conductor del vehículo como reo de un delito de homicidio, lesiones o daño a título de dolo. Condenar en la propia sentencia a la compañía aseguradora al pago de la indemnización impuesta choca con los esquemas propios del seguro de responsabilidad civil".

\section{Aplicación del precepto a los seguros de responsabilidad civil. Especial referencia a la responsabilidad civil circulatoria}

Hemos indicado en el epígrafe anterior la incidencia que ha tenido la configuración de la acción directa del art. 76 LCS en el devenir del art. 19 LCS, en cuanto a la interpretación que se ha hecho por nuestro TS de la inasegurabilidad del dolo. Del mismo modo, debemos señalar que en las distintas posiciones que se han ido manteniendo en cuanto a la cobertura o no por parte de las aseguradoras de los hechos dolosos de sus asegurados, siempre ha estado latente la responsabilidad derivada de la circulación de vehículos a motor, por su extensa regulación y por su casuística, trasladándose los criterios adoptados a otros seguros de responsabilidad civil previstos para otras actividades.

Como hemos apuntado, hasta la STS (Sala 2a) de 29 de mayo 1997 (RJ 1997/ 3637), el TS, salvo excepciones, como las SSTS (Sala $2^{\mathrm{a}}$ ) de 21 de noviembre de 1994 (RJ 1994/9213) y de 12 de noviembre de 1994 (RJ 1994/8917), mantenía que los hechos dolosos no tenían cabida dentro del seguro de responsabilidad. Sirva como ejemplo la STS (Sala 2a) de 10 de julio de 1995 (RJ 1995/5438), que, además, analizaba un supuesto de cobertura dentro del Seguro Obligatorio de Automóviles: "En el seguro obligatorio estas características de objetivación se acentúan, pero sin llegar a anular la autonomía (limitada eso sí) de los contratantes y los hechos dolosos no pueden ser previstos en ningún contrato como causa de obligatoriedad o subrogación del asegurador en la responsabilidad civil del delito de ese carácter, pues no se puede garantizar la realización de un acto ilícito. Aunque en la doctrina científica no falten opiniones discrepantes por lo que toca al seguro obligatorio, en la jurisprudencia de esta Sala ha prevalecido la posición contractualista, excluyente de los hechos dolosos. Y, precisamente, porque el Consorcio se subroga en la posición del asegurador privado, no cabe otra obligación".

Sin embargo, esta cuestión fue estudiada y resuelta por la Sala segunda del TS tras los acuerdos adoptados por los plenos no jurisdiccionales de 14 de diciembre de 1994 y 6 de marzo de 1997, habiéndose aprobado en este último que las sentencias condenatorias por delitos dolosos o culposos cometidos con vehículo de motor que determinen responsabilidad civil para las víctimas, deben incluir la condena a la entidad aseguradora dentro de los límites del seguro obligatorio, siempre que el daño se haya ocasionado con motivo de la circulación. 
En consecuencia, a partir de esos acuerdos del pleno de la Sala Segunda, hubo cierta unanimidad en la jurisprudencia a la hora de condenar como responsables civiles a las compañías aseguradoras por hechos dolosos ${ }^{16}$.

No obstante, al menos en materia de circulación, la cuestión fue regulada por el apartado 3 del art. 3 del Reglamento sobre Responsabilidad Civil y Seguro en la Circulación de Vehículos a Motor, aprobado por el RD 7/2001 de 12 de enero, que, en consonancia con el art. 1.4 de la Ley que desarrolla (LRCSCVM) y que fue modificado por la art. 71 de la Ley 14/2000 de 29 de diciembre, de medidas fiscales, administrativas y de orden social, prescribe que: "en todo caso no se considerarán hechos de la circulación los derivados de la utilización del vehículo como instrumento de la comisión de delitos dolosos contra las personas y los bienes".

Con esta redacción, a partir de la entrada en vigor de esta norma, pensábamos que quedarían fuera de la cobertura aseguradora los hechos dolosos ocasionados por los conductores de vehículos a motor y que esta cuestión, al menos en el ámbito circulatorio, estaba resuelta. De este modo, la SAP de Sevilla (Sección 1 ${ }^{\mathrm{a}}$ ) de $\mathbf{3 0}$ de diciembre de 2000 (ARP 2000/3109) afirmó con rotundidad que con la modificación del artículo 1.4 de la LRCSCVM quedaban despejadas definitivamente por el legislador las posibles dudas interpretativas. Esta sentencia, además de enumerar las razones que conducen a la exclusión de los hechos dolosos, considera que a ello se oponen no sólo los textos legales y los principios jurídicos, sino el texto expreso de la Ley.

Pues bien, como hemos indicado, esto no ha sido así, ya que el TS mantiene una postura diferente que nos hace pensar que el problema es insoluble, como ha puesto de manifiesto cuantas veces se ha pronunciado sobre la materia. A partir de la citada modificación legislativa, nos consta que se han dictado las siguientes

\footnotetext{
${ }^{16}$ Así lo entiende también, ARQUILLO COLET, B. "Acción directa..., op. cit. pág. 9, al indicar que para conciliar el art. 76 con el art. 19 de la Ley de Contrato de Seguro, con anterioridad al año 2000, se podía intuir la línea jurisprudencial siguiente: está prohibido asegurar el patrimonio contra las consecuencias negativas derivadas del dolo pero, por disposición expresa del art. 76 de la Ley de Contrato de Seguro, se obliga al asegurador a indemnizar si la persona que reclama es el tercero perjudicado, puesto que no se le puede oponer el dolo. a) El propio art. 117 CP (RCL 1995, 3170 y RCL 1996, 777), que se dice infringido, sin incluir la excepción que el recurrente indica (delitos dolosos), establece el derecho de repetición contra quien legalmente corresponda y lo hace con respecto a los daños causados como consecuencia de "un hecho previsto en este Código" (delito o falta) y por ende, tanto culposo como doloso. b) El art. 76 de la Ley de Contrato de Seguro (RCL 1980, 2295), específicamente aplicable, ya que nos hallamos ante un tercero perjudicado y por tanto víctima del delito, dispone: "el perjudicado o sus herederos tendrán acción directa contra el asegurador para exigirle el cumplimiento de la obligación de indemnizar sin perjuicio del derecho del asegurador a repetir contra el asegurado en el caso de que sea debido a conducta dolosa de éste, el daño o perjuicio causado a tercero». c) El art. 7. a) de la Ley de Responsabilidad Civil y Seguro en la Circulación de Vehículos de Motor (RCL 1995, 3046) establece: «El asegurador, una vez efectuado el pago, podrá repetir contra el conductor, el propietario del vehículo causante y el asegurado si el daño causado fuese debido a la conducta dolosa de cualquier de ellos». d) En la normativa comunitaria se parte del principio de cobertura por el seguro obligatorio a las víctimas de la circulación sin excluír los daños causados por eventos dolosos (Directivas 72/166 [LCEur 1972, 50], 84/5 [LCEur 1984, 9] y 90/232 [LCEur 1990, 450)
} 
sentencias: SSTS (Sala 2 ${ }^{\mathrm{a}}$ ) de 7 de febrero de 2001 (RJ 2001/358), 8 de abril de 2002 (RJ 2002/5093), 28 de octubre de 2003 (RJ 2003/8399), 23 de junio de 2004 (RJ 2004/5446), 20 de julio de 2004 (RJ 2004/5465), 29 de junio de 2006 y 11 de octubre de 2004 (RJ 2004/7890) (En esta última, aunque no analizaba un hecho de la circulación, hace alusión a los aseguramientos obligatorios, como el referente a la circulación vial, en los cuales la Sala, en Acuerdos Plenarios de fechas 14 de diciembre de 1994 y 6 de marzo de 1997, trató sobre la responsabilidad civil de las aseguradoras).

En todas ellas, con distintos matices, el TS mantiene la cobertura por parte de las aseguradoras de hechos dolosos. Sirva como ejemplo de su argumentación, la STS (Sala 2a) de 28 de octubre de 2003 (RJ 2003/8399). Esta Sentencia declara probado que el 25 de junio de 1999, D. Enrique se dirigió conduciendo su auto-taxi a las inmediaciones del estadio del C.F. Barcelona al objeto de contratar los servicios profesionales de alguna de las personas que ejercen la prostitución, alcanzando un acuerdo con D. Jesús Ángel para la realización de "un francés" por el precio de $12 \bullet$, subiéndose éste al vehículo del acusado y comenzando a prestar el servicio convenido. Tras una discusión, el acusado golpeó a D. Jesús Ángel, quién logró bajarse del taxi merced al auxilio de un compañero de profesión y cuando D. Jesús Ángel se alejaba del lugar donde estaba estacionado el taxi de D. Enrique, éste, con la intención de agredirle, puso en marcha su vehículo y lo dirigió contra aquél alcanzándole y atropellándole, produciéndole lesiones de gravedad. En la fecha de ocurrencia de los hechos, el vehículo propiedad de D. Enrique tenía concertado el seguro obligatorio con la entidad The Hartford.

La sentencia de la AP de Barcelona condenó al acusado como autor de un delito de lesiones a cuatro años de prisión y a indemnizar como responsable civil al perjudicado en la cantidad de $100.397,06 \bullet$, absolviendo a la entidad de seguros al tratarse de hechos dolosos excluidos de cobertura.

Ante los recursos de casación de ambas partes, el TS estima en parte el de la acusación particular, que denuncia, entre otros motivos, infracción del art. 76 de la LCS y condena como responsable civil a la compañía aseguradora por entender que los hechos enjuiciados tienen cabida dentro del seguro obligatorio.

El TS, en nuestra opinión, ignorando la reforma del art. 1.4 de la LRCSCVM o haciendo una interpretación muy particular de la misma, habla de los acuerdos de la Sala a los que hemos hecho alusión e indica que esa doctrina parte de la idea, reflejada en la STS n 179/1997, de 29 de mayo, de que "el seguro obligatorio de responsabilidad civil derivada de la circulación de vehículos a motor no constituye tanto un medio de protección del patrimonio del asegurado como un instrumento de tutela de los terceros perjudicados. En consecuencia, se trata de amparar a las víctimas frente al riesgo generado por la circulación de vehículos de motor, dando cobertura a las indemnizaciones procedentes con independencia de que el evento generador del daño sea un ilícito civil o un ilícito penal, sea culposo o doloso, siempre que el daño se haya cometido con un vehículo de motor y con motivo de la circulación".

El alto Tribunal estima que, para estos supuestos, la solución puede obtenerse 
aplicando el criterio recogido en la "Convención Europea sobre la Responsabilidad Civil en caso de daños causados por vehículos automóviles" del Consejo de Europa (1973) Su artículo 11 define las excepciones a la aplicación de la Convención y dispone que la cobertura del seguro quedaría excluida cuando se utiliza un vehículo "exclusivamente" como instrumento del delito, pero no cuando utilizándose el vehículo como medio de transporte (es decir, para desplazarse o circular por vías públicas o privadas abiertas a la circulación) se aprovecha para ocasionar deliberadamente un daño a un tercero mientras se circula. Este fue el argumento que plasmó en la STS (Sala $2^{\text {a) }}$ de 7 de febrero de 2001 (RJ 2001/358), en la que, tras citar el artículo reformado 1.4 de la LRCSCVM, se añade que, en el caso examinado, en la resolución queda patente que fue en el curso de la conducción de su vehículo por el inculpado cuando éste se apercibió de que por su izquierda adelantaba la joven -que había trabajado en la empresa que regía y con la que había tenido diversos problemas- en su motocicleta, y a pesar de encontrarse en caravana y sin posibilidad de adelantar, aquél efectuó el giro brusco a la izquierda con la única finalidad de provocar la caída de la joven y causarle lesiones. En esta situación, de acuerdo con la doctrina sustentada por la Sala, se estima claro el deber de indemnizar que recae sobre la aseguradora.

Resulta difícil de entender, en el supuesto que analizamos, que no se haya utilizado el vehículo como instrumento para la comisión de un delito doloso y sí para circular o como medio de transporte y se aproveche para ocasionar deliberadamente un daño a un tercero.

Más recientemente, en la STS (Sala $2^{\mathrm{a}}$ ) de 20 de julio de 2004 (RJ 2004/5465), aunque analiza un accidente de 1999, anterior a la reforma indicada, el TS cita el art. 1.1 de la LRCSCVM para decir que no deberán admitirse más excepciones a la responsabilidad que las establecidas en el propio art. 1 y 2 , y en ellos no se incluyen los delitos dolosos, cuando en el art. 1.4, tras la reforma, se refiere expresamente a su exclusión. Además, olvidándose de la reforma, enumera los argumentos legales para la cobertura por el Seguro Obligatorio de los hechos dolosos ${ }^{17}$

\footnotetext{
${ }^{17}$ Estos argumentos son los siguientes: La parte recurrente no puede ignorar que los límites del seguro obligatorio, a la hora de indemnizar perjuicios causados dolosamente en la circulación, los establece de forma específica su Ley reguladora, esto es, la Ley sobre Responsabilidad Civil y Seguro en la Circulación de Vehículos a Motor ( RCL 1995, 3046). En su art. 1-1 se señala que "el conductor de vehículos a motor es responsable, en virtud del riesgo creado por la conducción del mismo, de los daños causados a las personas o a los bienes con motivo de la circulación». En principio, no deberán admitirse más excepciones a la responsabilidad que los establecidas en el propio artículo $1^{\circ}$ y $2^{\circ}$, y en ellos no se incluyen los delitos dolosos. Cuando la responsabilidad la tiene que hacer efectiva el Seguro Obligatorio o en su caso el Consorcio de Compensación de Seguros, se establece igualmente su alcance en los arts. $4^{\circ}$ y $5^{\circ}$, en los que tampoco se hace referencia, para excluirlos de la cobertura, a daños ocasionados como consecuencia de la comisión de delitos dolosos "con motivo de la circulación". Cuando el vehículo es robado, como es la hipótesis concernida, la responsabilidad se traslada del seguro obligatorio ordinario al Consorcio (art. 5-3 ${ }^{\circ}$, en relación al 8.1c) de la misma Ley reguladora), pero tampoco este último precepto, en sus excepciones, excluye a los delitos dolosos como origen del daño indemnizable. Realmente, el ámbito de cobertura debe ceñirse al que estos preceptos específicos (y sus concordantes) definen
} 
Por lo dicho, para el TS sólo estaremos ante un hecho ajeno a la circulación cuando se utiliza el vehículo con el único propósito de cometer un delito doloso. Si se utiliza como medio de transporte y se aprovecha para ocasionar un daño a un tercero, estaremos dentro del ámbito circulatorio y deberá responder la entidad aseguradora o el Consorcio de Compensación de Seguros, en su caso. Así lo indicó también la STS (Sala 2a) de 8 de abril de 2002 (RJ 2002/5093), refiriéndose nuevamente a la Convención Europea de Responsabilidad Civil: "En consecuencia, los casos conflictivos quedarían limitados a los supuestos de dolo directo proyectado sobre el resultado. Para estos supuestos estimamos que la solución puede obtenerse aplicando el criterio recogido en la «Convención Europea sobre la Responsabilidad Civil en caso de daños causados por los vehículos automóviles», del Consejo de Europa (1973), cuyo art. 11 define las excepciones a la aplicación de la Convención, y se dispone que la cobertura del seguro quedaría excluida cuando se utiliza un vehículo "exclusivamente" como instrumento del delito, pero no cuando utilizándose el vehículo como medio de transporte, es decir para desplazarse o circular por vías públicas o privadas abiertas a la circulación, se aprovecha para ocasionar deliberadamente un daño a un tercero, mientras se circula".

Estos argumentos del TS referidos a los hechos de circulación, se han trasladado en los últimos años a otros seguros de responsabilidad civil, condenando igualmente a las entidades aseguradoras por los hechos intencionados de sus asegurados o de las personas por las que deben responder.

En esta línea, se han condenado a entidades aseguradoras por delitos de abusos sexuales, lesiones u homicidios cometidos por empleados de empresas que,

legalmente, sin introducir la distorsionante distinción entre delitos dolosos y culposos. Las sentencias de esta Sala núm. 179 de 29 de mayo de 1997 (RJ 1997, 3637) y núm. 770, de 24 de octubre de 1997 (RJ 1997, 7768), han sentado definitivamente la doctrina que se apunta. De ellas fluyen argumentos legales que refuerzan la cobertura del Seguro Obligatorio (en este caso el Consorcio) en supuestos de eventos dañosos provocados por hechos de carácter doloso, consecuencia de la circulación, cuando el vehículo es robado. Señalemos las siguientes:

a) El propio art. 117 CP (RCL 1995, 3170 y RCL 1996, 777), que se dice infringido, sin incluir la excepción que el recurrente indica (delitos dolosos), establece el derecho de repetición contra quien legalmente corresponda y lo hace con respecto a los daños causados como consecuencia de un hecho previsto en este Códigon (delito o falta) y por ende, tanto culposo como doloso.

b) El art. 76 de la Ley de Contrato de Seguro (RCL 1980, 2295), específicamente aplicable, ya que nos hallamos ante un tercero perjudicado y por tanto víctima del delito, dispone: "el perjudicado o sus herederos tendrán acción directa contra el asegurador para exigirle el cumplimiento de la obligación de indemnizar sin perjuicio del derecho del asegurador a repetir contra el asegurado en el caso de que sea debido a conducta dolosa de éste, el daño o perjuicio causado a terceron.

C) El art. 7. a) de la Ley de Responsabilidad Civil y Seguro en la Circulación de Vehículos de Motor (RCL 1995, 3046) establece: "El asegurador, una vez efectuado el pago, podrá repetir contra el conductor, el propietario del vehículo causante y el asegurado si el daño causado fuese debido a la conducta dolosa de cualquier de ellos».

d) En la normativa comunitaria se parte del principio de cobertura por el seguro obligatorio a las víctimas de la circulación sin excluír los daños causados por eventos dolosos (Directivas 72/166 [LCEur 1972, 50], 84/5 [LCEur 1984, 9] y 90/232 [LCEur 1990, 450) 
a su vez, han sido condenadas como responsables civiles subsidiarias. Es el caso contemplado en la STS (Sala 2a) de 17 de octubre de 2000 (RJ 2000/9152), en el que un socio trabajador de una cooperativa cuyo objeto era el cuidado de niños, fue condenado por un delito de abusos deshonestos, condenando también como responsable civil subsidiaria a la cooperativa y a su compañía aseguradora como responsable civil directa; o el analizado en la STS (Sala 2a) de 11 de marzo de 2002 (RJ 2002/6891), en el que el director de un centro dependiente de una parroquia comete el mismo delito y también se condena a la entidad aseguradora de responsabilidad civil de la parroquia.

Las SSTS (Sala 2a) de 22 de abril y 27 de mayo de 2002 (RJ 2002, 5454 y 7756), se refieren a delitos de lesiones cometidos por empleados de discotecas. El TS mantiene los mismos argumentos a los que nos hemos referido para condenar como responsables civiles a las aseguradoras que garantizaban la responsabilidad civil de estos establecimientos.

Sobre esta cuestión, tiene especial significación la STS (Sala 1ª) de 20 de julio de 2005 (RJ 2005/5099), porque es una sentencia de la Sala $1^{a}$ y de gran interés, al ser escasos, como es natural, sus pronunciamientos sobre hechos dolosos y tratar, además, sobre una materia que le es más propia que a la Sala $2^{\mathrm{a}}$, como es la responsabilidad civil.

Los hechos se refieren al asesinato de dos jóvenes que se encontraban en el interior de un vehículo por parte de un vigilante de seguridad que tenía encomendada la vigilancia de una cantera a unos 1.240 metros de donde se produce el delito.

Se siguió un procedimiento penal contra el vigilante y fue condenado como autor de dos delitos de asesinato y a indemnizar a cada uno de los padres de las víctimas en diez millones de pesetas, declarándose la responsabilidad civil subsidiaria de la empresa para la que prestaba sus servicios.

Ante la insolvencia de la empresa de seguridad, que tenía contrato un seguro de responsabilidad civil con la entidad Plus Ultra, los padres del varón fallecido ejercitaron la acción directa que les confiere el art. 76 LCS contra la aseguradora, que fue absuelta tanto en primera como en segunda instancia, por entender, básicamente, que el riesgo de actos delictivos no era asegurable, tal como defendía la entidad demandada.

Los actores interpusieron recurso de casación y el TS, aceptando sus motivos, casó la sentencia de instancia y estimando la demanda condenó a la aseguradora.

Argumenta, en primer lugar, el TS que el art. 1 LCS obliga al asegurador a indemnizar a los perjudicados "dentro de los límites pactados" y el 19 LCS le exime en el supuesto de mala fe del asegurado. Sin embargo, señala a continuación, que dichos preceptos son aplicables inicialmente a toda clase de seguros, "con la salvedad de lo que al respecto se diga para algún tipo o clase específicos de seguro".

Para la Sala $1^{\text {a }}$, el art. 76 LCS "(...) constituye una norma especial, y, por lo tanto, de preferente aplicación para el seguro de que se trata (conforme al principio de que la "Ley especial deroga a la Ley general en lo que aquélla regula») sobre la regla general del art. 19 (que eliminaría, para los seguros que no tienen esa prevención, 
la excepción a la responsabilidad de la aseguradora, por "mala fe» del asegurado, o sea, por conducta "dolosa» o "delictiva» del mismo)".

La sentencia hace suyos algunos de los argumentos esgrimidos en todas las sentencias analizadas por la Sala $2^{\mathrm{a}}$, como son la función de protección de las víctimas del seguro de responsabilidad civil y el art. $117 \mathrm{CP}$ que identifica con el art. $76 \mathrm{LCS}^{18}$.

Con esta sentencia de la Sala 1a, podemos decir que queda claro la posición del TS respecto a la cobertura de los daños dolosos por parte de las entidades aseguradoras que garantizan la responsabilidad civil del asegurado o de las personas por las que éste responde. Las aseguradoras "deben agradecer", en este caso, que la condena a los intereses del art. 20 LCS sea desde la fecha de la sentencia y no desde la fecha del siniestro, porque, evidentemente, existían causas justificadas para que la aseguradora no pagara extrajudicialmente.

No faltan voces discrepantes de esta doctrina o, al menos, que hacen una interpretación distinta de lo que se entiende, en el ámbito circulatorio, por "utilización del vehículo como instrumento para la comisión de delitos dolosos". El TS señala en las sentencias que hemos mencionado que sólo en estos casos se libera a la aseguradora de acuerdo con la normativa citada. Sin embargo, curiosamente, en ninguno de los casos que estudia entiende que se ha utilizado el vehículo de motor en ese sentido.

No lo hace así la SAP de Madrid (Sección 23a) de 22 de mayo de 2006 (ARP 2006/447), en el que en un supuesto similar a los estudiados y utilizando los argumentos del TS, libera al Consorcio de Compensación de Seguros, al entender que en este caso sí se utilizó el vehículo como instrumento para la comisión de un delito doloso.

El condenado por estos hechos se montó en un vehículo de su propiedad y se

\footnotetext{
${ }^{18}$ Así, indica: F) Es de mantener también, como se dice en la motivación del Recurso, la razonable fundamentación de las sentencias en ella recogidas, en cuanto a distinguir la eficacia del contrato de seguro de responsabilidad civil en dos frentes, el propio del mismo asegurado, en relación con la preservación o protección de su particular patrimonio, y el general, de instrumento de tutela (sea el seguro obligatorio o voluntario) de los derechos de las víctimas o perjudicados (desarrollo del amparo dentro del aspecto de la victimología, tan protegido en otros derechos, como el francés), por lo que en la actuación jurídica de la póliza en este caso, y dada la insolvencia del responsable directo, y del subsidiario del mismo, primaría este último aspecto. G) Por último, y como simple apoyo a esta tesis, aquí desarrollada, se puede traer también a colación un fundamento jurídico, aunque aquí no directamente aplicable, como lo es el establecido asimismo en el CP hoy vigente (LO 10/1995, de 23 de noviembre [RCL 1995, 3170 y RCL 1996, 777] , del Código Penal), cuyo art. 117 (incluido en el Libro I, sobre "Disposiciones Generales» y en su Título V, sobre "la responsabilidad civil derivada de los delitos y faltas", y cap. II, "de las personas civilmente responsables») dice, en lo que aquí interesa, que "los aseguradores que hubieren asumido el riesgo de las responsabilidades pecuniarias derivadas del uso o explotación de cualquier bien, empresa, industria o actividad, cuando, como consecuencia de un hecho previsto en este Código, se produzca el evento que determine el riesgo asegurado, serán responsables civiles directos hasta el límite de la indemnización legalmente establecida o convencionalmente pactada, sin perjuicio del derecho de repetición contra quien corresponda», el que estaría en total consonancia con el art. 76 LCS (RCL 1980, 2295), cuyo contenido reitera con la directa referencia a los hechos delictivos.
} 
dirigió a las inmediaciones de un bar para esperar a que salieran del mismo dos personas. Una vez que salieron, puso en marcha su vehículo y con la intención de quitarles la vida los arrolló, causándoles graves lesiones.

La sentencia, después de citar las últimas resoluciones del TS sobre la cuestión, absuelve al Consorcio de Compensación de Seguros, señalando lo siguiente: "Así pues, a la luz de la jurisprudencia y normativa citada, el Consorcio no ha de ser condenado, ya que los hechos que se enjuician no se cometen con motivo de la circulación, sino que se ha utilizado un vehículo de motor con el fin exclusivo de acometer contra las víctimas. Es más, no es que el acusado fuese circulando con el coche en busca de esas víctimas, sino que las espera al acecho en una acción planificada, al único fin de embestir contra ellas, guiado de un dolo directo proyectado al resultado, como dice el Tribunal Supremo, que, precisamente, por ello, exculpa de cualquier responsabilidad al indicado organismo".

En esta línea, en una de las últimas veces que se ha pronunciado el TS sobre esta materia, en la STS 742/2006 (Sala 2a) de 29 de junio de 2006, pese a que la opinión mayoritaria mantiene los criterios expuestos y condena a la entidad aseguradora por un hecho doloso de su asegurado, vemos que el Ministerio Fiscal y un Magistrado que emitió un voto particular, disienten de la opinión mayoritaria, en el sentido de no considerar como hechos de la circulación cuando se utiliza el vehículo a motor como instrumento para la comisión de delitos dolosos, solicitando, en consecuencia, la no cobertura por la aseguradora de tales hechos.

Para el Magistrado disidente "El sostener que, como el vehículo "circula" cuando el delito intencionado con él se comete, estamos ante un «hecho de la circulación», y no "exclusivamente» delictivo con carácter doloso, constituye, a mi juicio, un argumento de un reduccionismo prácticamente absurdo, dicho sea con todos los respetos".

Esto nos hacía pensar que en el seno de la propia Sala $2^{\mathrm{a}}$ existían voces que discrepaban del criterio de la mayoría, lo que indicaba, cuando menos, que la construcción doctrinal del alto tribunal para dar cobertura a estos supuestos por parte de las aseguradoras tenía ciertas fisuras, por lo que no sería extraño que en el futuro nos encontráramos con un cambio de rumbo en su doctrina sobre esta cuestión, que fuera más acorde con lo preceptuado en la normativa que regula la responsabilidad civil en la circulación de los vehículos a motor.

Y esto es precisamente lo que ocurrió con la STS (Sala 2a) de 8 de mayo de 2007 (RJ 2007\2873) 192021 , en la que parece que se reconduce la situación,

\footnotetext{
${ }^{19}$ Vid. comentario de esta sentencia de REGLERO CAMPOS, F. "Los daños dolosos y el hecho (o accidente) de la circulación" (Notas a la Sentencia de la Sala $2^{\mathrm{a}}$ del Tribunal Supremo de 8 de mayo de 2007), Revista de Responsabilidad Civil, Circulación y Seguro, Nº 7, julio-agosto 2007, pág. 48 y ss.

${ }^{20}$ También se refiere a esta sentencia, YZQUIERDO TOLSADA, M., "Evolución de la responsabilidad civil y el seguro de responsabilidad civil en los últimos 10 años", $X$ Congreso de Responsabilidad Civil y Seguro, INESE, Madrid, octubre, 2008, pág. 20 y ss.

${ }^{21}$ Para MAZA MARTÍN, J.M., "Jurisprudencia del dolo..., op. cit., pág. 6, este acuerdo representa, o al menos debería representar, una verdadera inflexión en la línea doctrinal seguida hasta ese
} 
estableciendo una nueva doctrina que, en síntesis, excluye de los hechos de la circulación la utilización de un vehículo a motor como instrumento para la comisión de delitos dolosos.

Sin duda, el asunto se había vuelto a debatir en el seno del alto tribunal y por ello la citada sentencia transcribe el acuerdo $n^{\circ} 1 / 2007$ de la Sala General de la Sala $2^{\mathrm{a}}$ del TS de 24 de abril de 2007 (JUR 2007\130518)22, que establecía lo siguiente: "No responderá la aseguradora, con quien se tenga concertado el seguro obligatorio de responsabilidad civil, cuando el vehículo de motor sea el instrumento directamente buscado para causar daño personal o material derivado del delito. Responderá la aseguradora por los daños diferentes de los propuestos directamente por el autor"

Aunque de este acuerdo quedan por despejar algunas dudas, pues parece que sólo quedan fuera los daños directos intencionados (dolo directo de primer grado), pero no aquellos daños superiores a los deseados, al menos, ha servido para clarificar y poner algo más de sensatez a esta cuestión. A raíz de este acuerdo, se han dictado sobre esta cuestión las siguientes SSTS: STS (Sala 2a), de 8 de mayo de 2007 (RJ 2007\2873), STS (Sala $2^{\mathrm{a}}$ ) de 10 de mayo de 2007 (RJ 2007\4732), STS (Sala $2^{\mathrm{a}}$ ) de 7 de octubre de 2009 (JUR 2009\443921) y STS (Sala 2a) de 3 de noviembre de 2009 (JUR 2009\482339), que, utilizando argumentos similares a la indicada tras el acuerdo de Sala, consideran, en general, que no responde el seguro concertado cuando el vehículo es el instrumento directamente buscado para causar el daño personal o material.

En todo caso, parece que la STS (Sala 2a) de 27 de febrero de 2009 (RJ 2009 (3290), sobre el caso Maeso, quizá inducida por el tratamiento que el Tribunal de instancia y la propia recurrente dieron a la cuestión debatida, ha venido a reabrir la antigua polémica, aplicando argumentos, sobre la extensión del aseguramiento a las conductas dolosas, que ya deberían estar hoy superados, cuando además todo ello se hace en relación con un ámbito esencialmente distinto de aquel desde el que se importa la referida doctrina y habiendo podido resultar mucho más sencillo y correcto buscar la solución desde otros planteamientos de más directa vinculación con el objeto del enjuiciamiento ${ }^{23}$.

momento por la Sala Segunda, aunque sólo sea porque supone el reconocimiento de esa necesidad de tener que replantear su doctrina tras las reformas legales y la incorporación, prácticamente literal, de los innovadores preceptos que, a su vez, significan una indudable voluntad del Legislador de corregir la anterior interpretación, único motivo que justifica las reformas.

${ }^{22}$ Para YZQUIERDO TOLSADA, M. "Evolución de la responsabilidad civil..., op. cit., desde el Acuerdo General de 24 de abril de 2007, cuando alguien está utilizando el automóvil como medio de transporte, y aprovechando la circunstancia, arremete contra un tercero, queda excluida la cobertura del seguro porque eso tampoco es un hecho de la circulación. A diferencia de lo que sucede con los supuestos de dolo eventual (conductores kamikazes; conductores que para huir del control policial se llevan por delante en su alocada huida a quien por delante se ponga; conductores ebrios o drogados), en que el asegurador tendrá que pagar al perjudicado y luego podrá repetir del asegurado, aquí la exclusión de la cobertura es total y absoluta, y no sólo inter partes.

${ }^{23}$ Así lo indica, MAZA MARTÍN, J.M., "Jurisprudencia del dolo..., op. cit.., pág. 16. 


\section{ASEGURABIIDADDE LA CULPA GRAVE}

En principio, entendemos que la culpa grave la debe asumir el asegurador, porque el art. $19 \mathrm{LCS}$, como hemos visto, se refiere a "mala fe" del asegurado, que es equiparable al dolo y no a la culpa grave. Por ello, habrá que estar a lo previsto en la póliza para poder excluir los daños ocasionados interviniendo culpa grave del asegurado. Lo único que está excluido por la ley son los daños intencionados, no los culposos, aun mediando culpa grave.

Así lo pone de manifiesto la STS (Sala 2a) de 27 de noviembre de 1989 (RJ 1989/9326), en un supuesto de conducción bajo la influencia de bebidas alcohólicas: "En relación con esta cuestión, es preciso tener en cuenta que, según establece el artículo 19 de la Ley de Contrato de Seguro, «el asegurador estará obligado al pago de la prestación salvo en el supuesto de que el siniestro haya sido causado por mala fe del aseguradon. De ello cabe concluir que es asegurable la culpa del asegurado sea grave o leve- y que, por ende, en estos supuestos quedará obligada la entidad aseguradora (vid. artículo 73 de la Ley de Contrato de Seguro). Es decir, que únicamente quedan fuera del ámbito potencial del contrato de seguro de responsabilidad civil la responsabilidad penal propiamente dicha y la civil «derivada de hechos dolososı".

Éste es también el criterio que han mantenido las Audiencias Provinciales, como muestran las recientes sentencias de las AAPP de Baleares (Sección 4ª) de 18 de marzo de 2005 (JUR 2005/115505, de Almería (Sección 2a) de 3 de febrero de 2004 (AC 2004/566), de Guadalajara (Sección 1ª) de 25 de septiembre de 2004 (JUR 2004/ 47894) y de Sevilla (Sección $1^{\text {a }}$ de 14 de julio de 2003 (ARP 2003/711).

Ahora bien, en el caso que se pacte convencionalmente la exclusión del siniestro ocasionado por culpa grave, entendemos, que este pacto sería válido en las relaciones asegurador-asegurado, donde aquél podría oponer la excepción de culpa grave del asegurado en la causación de los daños para liberarse de indemnizar. Sin embargo, en los seguros de responsabilidad civil, como ocurre en los supuestos analizados de hechos intencionados, habría que aplicar frente a terceros el régimen previsto, como preferente del art. 76 LCS e indemnizar a los terceros perjudicados.

En todo caso, estas cláusulas de exclusión, según la jurisprudencia mayoritaria, deber cumplir los requisitos del art. 3 LCS, por considerarse cláusulas limitativas de los derechos del asegurado. Así lo puso de manifiesto, pese a la oposición de la aseguradora que entendía que era una cláusula delimitadora del riesgo y no limitativa de los derechos del asegurado, la STS (Sala $1^{\mathrm{a}}$ ) de 9 de noviembre de 1990 (RJ 1990/8535), al establecer: "(...) la «imprudencia grave» excluida en la póliza, que no en la Ley, tenía que ser objeto de una expresa aceptación por parte del tomador del seguro, único extremo que le daría validez, lo que concuerda igualmente con la exigencia de precisión y claridad, dada la naturaleza de contrato de adhesión que le alcanza; y se refuerza el criterio mantenido cuando tal imprudencia grave o actuar temerario puede, cual afirma el recurrente, «equipararse al dolo eventual o a la intencionalidad de la lesión", predicamento no aplicable tampoco al supuesto de 
autos recogido en el primer fundamento de esta resolución, lo que haría que, aun acogiéndose algún motivo (mera hipótesis), tampoco transcendiese al fallo, con inviabilidad de la casación pretendida, pues la imprevisión de dormir en lugar cerrado y con brasero encendido en modo alguno puede equipararse a intencionalidad directa, indirecta o eventual, ni a culpa con representación, ni a actuar consciente, so pena de pretender un actuar cuasi suicida, que en momento alguno se ha postulado; a lo más existiría una omisión de normas que, por no ser inexcusables o aconsejadas por la más vulgar experiencia, sólo pueden exigirse en contados casos, constituyendo mera imprudencia simple, que no anularía la obligación contraída por la aseguradora. Por último, afirma que la delimitación del riesgo, en aspecto tan trascendente, no equivale a limitación de derechos, que requiere aceptación específica (no concurrente, según la Sala de Instancia: apreciación de hecho no atacada adecuadamente) constituye valoración subjetiva e interesada, rechazable ante la lógica, imparcial y objetiva de la resolución recurrida".

Pese a que alguna Audiencia Provincial o Tribunal Superior de Justicia, como lo muestran las sentencias de la AP de Valencia (Sección 6a) de 31 de octubre de 2004 (JUR 2004/49775) y 30 de enero de 2003 (AC 2003/821) y STSJ del País Vasco (Sala de lo Social, Sección 8a) de 2 de julio de 2004 (JUR 2005/42098), se pronuncian en el mismo sentido que el TS, entendemos con Sánchez Calero ${ }^{24}$, que en estos supuestos estamos ante una delimitación causal del riesgo, que no ha de equipararse a una cláusula limitativa de los derechos del asegurado.

En cuanto al derecho de repetición que establece el art. 76 LCS contra el asegurado, en los supuestos en los que haya sido intencionada la conducta de éste, nos preguntamos si también puede repetir la entidad aseguradora en los supuestos de culpa grave. En definitiva, si se puede equiparar, a estos efectos, el dolo y la culpa grave. Yzquierdo Tolsada ${ }^{25}$ entiende que si la ley no dispone otra cosa, la culpa lata se equipara al dolo en el terreno del seguro de responsabilidad civil. Por tanto, el derecho de repetición del art. 76 LCS, pese la dicción literal de texto, se puede ejercitar en los casos de culpa grave.

\section{A MODO DE COROLARIO}

El aseguramiento de la culpa, incluso la grave, no ha planteado problemas y, salvo excepciones, como el seguro de robo, se ha entendido que tiene cabida dentro del contrato de seguro. El seguro debe cubrir, entre otros riesgos, la negligencia del asegurado, porque este es uno de sus fines esenciales.

Sin embargo es más difícil de entender y de justificar la cobertura -que no el aseguramiento- de los hechos dolosos causados por los asegurados o por las personas por los que debe responder. Y ello es porque ni en la teoría general de los contratos ni en el propio contrato de seguro, tienen cabida las conductas intencionadas de las

${ }^{24}$ Vid. SÁNCHEZ CALERO, F., Comentarios a la Ley 50/1980, de 8 de octubre y a sus modificaciones, $3^{\text {a }}$ edición, Cizur Menor (Navarra), Aranzadi, junio 2005, pág. 361.

${ }^{25}$ Vid. YZQUIERDO TOLSADA, M., Aspectos civiles, op. cit., pág. 210. 
partes. Los contratantes, señala el art. 1255 CC "pueden establecer los pactos, cláusulas y condiciones que tengan por conveniente, siempre que no sean contrarios a las leyes, a la moral ni al orden público".

Así mismo, el elemento más característico del contrato de seguro es "el alea, el azar o la aleatoriedad", que significa que el evento dañoso no ha de depender de la voluntad de las partes, bien de manera absoluta, bien de manera relativa. Por tanto, todo aquello que dependa de la voluntad de las partes debe ser ajeno al aseguramiento y a la cobertura del contrato de seguro, como indica que art. 19 LCS: "El asegurador estará obligado al pago de la prestación, salvo en el supuesto de que el siniestro haya sido causado por mala fe del asegurado". Además, como hemos señalado, para que no haya equívocos, las propias pólizas de seguro excluyen de forma expresa la cobertura de los hechos dolosos de los asegurados.

Sin embargo, pese a estos razonamientos, la cobertura por parte de las entidades aseguradoras de los hechos dolosos de los asegurados, ha sido una realidad y uno de los asuntos más debatidos, sobre todo a nivel jurisprudencial, en el ámbito del seguro y más en concreto en el seguro de responsabilidad civil. Esto ha sido así porque desde hace unas décadas, el Tribunal Supremo ha concebido este seguro, no como un seguro de deudas que pretende proteger el patrimonio del asegurado, sino como un seguro cuyo fin es la protección de terceros perjudicados. En consecuencia, se dice en algunas sentencias relativas a la responsabilidad civil de la circulación, "se trata de amparar a las víctimas frente al riesgo generado por la circulación de vehículos de motor, dando cobertura a las indemnizaciones procedentes con independencia de que el evento generador del daño sea un ilícito civil o un ilícito penal, sea culposo o doloso, siempre que el daño se haya cometido con un vehículo de motor y con motivo de la circulación".

En efecto, al seguro de responsabilidad civil se le ha dado por parte de la jurisprudencia una dimensión social y para ello, para justificarlo, se ha acudido al art. 76 LCS, que establece la acción directa del perjudicado frente al asegurador. Esta acción lo que pretende, en definitiva, es proteger al tercero perjudicado, que es ajeno a la relación jurídica asegurado-asegurador y dentro de este marco se podría decir que tiene cabida la cobertura de los hechos dolosos ocasionados por el asegurado, sin perjuicio del derecho de repetición que tendría el asegurador frente a su asegurado, una vez que haya indemnizado al tercero perjudicado.

Por la casuística que ha habido, esta teoría sobre la cobertura de los hechos dolosos de los asegurados, se ha desarrollado, sobre todo, en el seguro de responsabilidad civil en la circulación de vehículos a motor, expandiéndose a otros seguros, también de responsabilidad civil. De este modo, los acuerdos de la Sala $1^{\text {a }}$ del Tribunal Supremo de 1994 y 1997 sobre esta cuestión, en los que se decidieron la cobertura por parte de las aseguradoras de los hechos intencionados de los asegurados, fueron sobre la base de accidente de circulación.

En este ámbito, como resultaba incoherente la cobertura de estos actos, el propio legislador, consciente de la situación, modificó en el año 2000 la Ley sobre 
Responsabilidad y Seguro en la Circulación de Vehículos a Motor, en el sentido de no considerar hechos de la circulación la utilización del vehículo a motor como instrumento para la comisión de delitos dolosos.

Pese a ello, como hemos puesto de relieve en este estudio, el Tribunal Supremo, hasta el último acuerdo de Sala $2^{\mathrm{a}}$ de 24 de abril de 2007, ha ignorado esta modificación legislativa y, en líneas generales, ha mantenido la cobertura de los hechos dolosos de las asegurados. Así, con distintos argumentos, según los casos, ha condenada en todas sus sentencias hasta esa fecha a las entidades aseguradoras como responsables civiles por actos intencionados de sus asegurados.

Después de este acuerdo de Sala $2^{\mathrm{a}} 24$ de abril de 2007, que ha sido reflejado en sus posteriores sentencias, las dos últimas, de 7 de octubre y el 2 de noviembre de 2009, no podemos decir que la cuestión está resuelta, pero sí que ha habido un avance considerable de la Sala y que, al menos, existe cierta seguridad jurídica.

La cuestión no está resuelta, a mi modo de ver, porque no se entiende bien que sólo se libere a las aseguradoras en los supuestos en los que el autor del hecho intencionado haya sido condenado por haber cometido la acción por dolo directo de primer grado y no por otras formas dolosas, como puede ser el dolo eventual. ¿Es que el dolo eventual no es igualmente dolo? No olvidemos que el Código Penal no distingue entre las distintas formas dolosas. Esta norma sólo castiga el dolo, siendo el dolo eventual o el dolo de segundo grado una construcción jurisprudencial. 